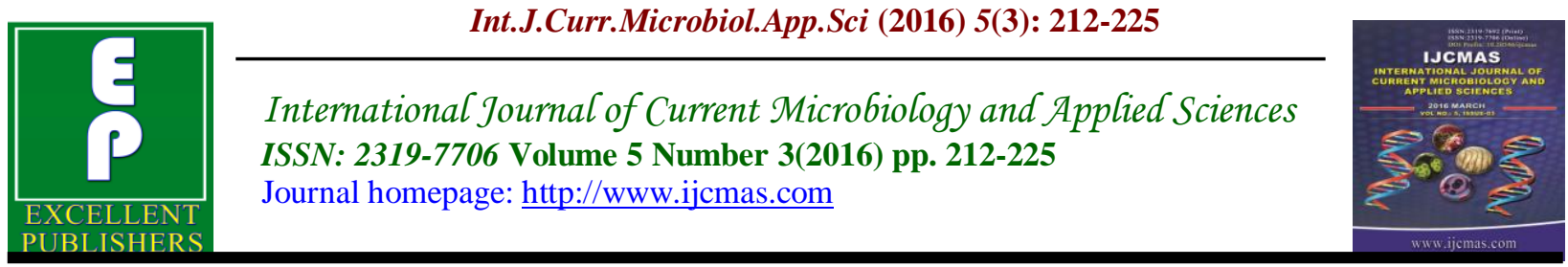

Original Research Article

http://dx.doi.org/10.20546/ijcmas.2016.503.026

\title{
Phytoremediation Ability of Calotropis procera in Reducing Air Pollution in Jeddah City-Kingdom of Saudi Arabia
}

\author{
Batoul Mohamed Abdullatif*, Molouk Mohamed El-Kazan and Maram Ali Al-Zahrani \\ Department of Biological Sciences, Faculty of Science, King Abdulaziz University, \\ Jeddah, Saudi Arabia \\ *Corresponding author
}

\begin{abstract}
A B S T R A C T
Keywords

Phytoremediation, Calotropis

procera,

Cement factory,

Air pollution,

Heavy elements.

Article Info

Accepted:

15 February 2016

Available Online:

10, March 2016

This study was conducted in Northeastern part of Jeddah city. Calotropis procera plant was used as bioindicator and phytoremediator of contamination with heavy metals arising from the cement factory located in this area. Three study sites were chosen, the first site (control) where C. procera plants growing $4.88 \mathrm{~km}$ far away from the polluted area (the cement factory) and the other sites at the cement factory has also been divided into two sites the first one include $C$. procera plants growing around the factory (location 2), the second site include $C$. procera plants growing 150 meters far away from the factory (location 1). Samples of plants and soils were collected during summer and winter seasons (2013-2014) for laboratory works. Amount of some heavy elements (Aluminum, Chromium, Boron, Barium, Copper, Manganese, Iron, Lead and Zinc), were estimated, in plants and soil. Results revealed that, $C$. procera has the ability to have reasonable amount of heavy elements at normal ranges. Worth mentioning is that soil heavy elements were less than in plants, indicating the phytoremediation ability of this plant in cleaning the soil, meaning that, this plant absorbs the pollutants from the atmosphere. It is noticeable that heavy elements accumulated more during winter season in plants and during summer season in soil. Therefore, C. procera can be used as protective belts near polluted areas in Jeddah.
\end{abstract}

\section{Introduction}

Phytoremediation, a technology that include the use of higher plants to clean polluted environments (Hifsa et al., 2010 a and b). Phytoremediation is therefore considered as an economic technology. This branch of research is limited by scarce knowledge of basic plant remedial mechanisms. Improvements of element polluted soil have many obstacles. Metals normally cannot be degraded as do organic pollutants. Generally, cleaning of metal-polluted soil needs the cleaning of toxic metals. Recently, phytoextraction, which is mainly plant extracts to remove toxic metals from polluted soils, became economically good alternative to clean polluted soils. 
Examples of hazardous toxic elements that need bioremediation are Aluminium, Zinc, Manganese, Lead, Copper, Chromium, and Arsenic (Oyedepo, 2011). There are heavy metals in soil, natural water, air and be in different forms and may become contaminants in food and drinking water (Heng et al., 2009). Due to seriousness of such heavy metals in the environment for toxicity, they are not biodegradable but are subject to shift as well as the danger lies in their ability to accumulate in living organisms (Volesky, 1994; Volesky \& Holan, 1995; Al-Yemni et al., 2011, and Vaishnav et al., 2012).

Calotropis procera is a species of flowering plant in the family, Asclepiadaceae, which is common in North Africa, Tropical Africa, Western Asia, South Asia, and Indochina. The green fruits are empty but the moist part contains poisonous milk that is very bitter and cannot dissolve in soap (Oyedepo, 2011).

Hence, the objective of the present study is to evaluate whether using natural plants growing in Jeddah city can be useful tools in biomonitoring and phytoremediation programs as a protective belt near industrial areas in Jeddah city. In addition, because of the availability of Calotropis procera, and depending on its distribution in wide range in desert regions of Kingdom of Saudi Arabia, $C$. procera was used to assist as either a bio-indicator or a bio-accumulator for sediments polluted by nutrients and metals that threaten Jeddah city.

\section{Research Methodology}

\section{Sites Selection}

Three locations were taken according to the distances from the big cement factory (located northeastern Jeddah City, picture
2): 1- Control (4.88 $\mathrm{Km}$ away from the factory). 2- Location 1 (150 $\mathrm{m}$ away from the factory). 3- Location 2 (just around the factory).

\section{Samples Collection}

Plant and soil samples were collected during summer 2013 (from June to August) and during winter 2014 (from January to April). 15 leaves (from 5 plants, 3 leaves/ plant) were randomly collected from each of the three selected sites. The leaves were put in tied plastic bags for further studies. Some leaves were air dried grinded and kept in small bottles for further analyses. In addition, 15 homogenized soil samples were collected from the root zones of the same previous plants at depth of $30 \mathrm{~cm}$, using steel auger. Soil samples were scattered on clean papers in the laboratory (air drying) and then sieved through $2 \mathrm{~mm}$ sieve to remove gravel, stones and large suspended matters. Soils were mixed to obtain homologous samples for each location.

\section{Plant Sample Digestion}

Digestion of plant samples was conducted following the method of Stewart, (1983). 0.2 $\mathrm{g}$ of dry ground sample was weighed in 50 ml kjeldahl flask. 1-ml concentrated sulfuric acid $\left(\mathrm{H}_{2} \mathrm{SO}_{4}\right)$ was added to the sample in the flask. Samples were digested at a moderate heat in the fume cupboard until white fume evolved. The heat was intensified further for few minutes to be completely homogenized in black color, and then allowed to cool. 1 $\mathrm{ml}$ from a mixture of Sulfuric and Perochloric acids (1:1) was added to the sample. The samples were heated again until they were colorless indicating complete digestion. The volume of each sample was diluted to $50 \mathrm{ml}$ using distilled water and then filtered through Whatman No.1 filter paper. A blank was prepared following the 
same procedure except that the plant sample was not added. These samples are kept refrigerated until use. The sample digests were analyzed in five replicates to measure heavy metals content using (ICP, Inductively Coupled Plasma-Optical Emission Spectrometry).

\section{Soil Sample Digestion}

A known weight of air dried soil samples was used for digestion following the procedure of Stewart, (1983). Equal amount of $60 \%$ perchloric acid and conc. nitric acid and conc. sulfuric acid were added to the soil samples in digestion flasks. At the same time blank samples were made using water instead of soil. Nitric acid was added to the soil samples. The samples were then put in a heater inside a gas cabinet using medium temperature until black fumes were noticed. Samples were left to cool, then perchloric acid and sulfuric acid (1:1) were added to the samples. Samples were re-heated using high temperature until the mixture turns into a light green or yellow liquid, and they were cooled again samples turned into a colorless transparent liquid and then left until the next day. Samples were centrifuged to get rid of soil particles and then transferred to a beaker and completed to 100 by distilled water. Samples were placed in glass containers in the refrigerator until use. The digested samples were analyzed in five replicates for macro and heavy metals content by (ICP) as was mentioned before.

\section{Estimation of Element Contents in Plants and Soils}

Heavy elements (Al, Cr, B, Ba, Cu, Mn, Fe, $\mathrm{Pb}$ and $\mathrm{Zn}$ ) were estimated in digested dry leaves and soils. The sample digests were analyzed in five replicates for each site using (ICP model 710 axial systems). (ICP OES) Inductively Coupled Plasma - Optical Emission Spectrometry. The elements amounts were expressed as $\mathrm{mg} / \mathrm{kg} / \mathrm{dry}$ weight.

\section{Statistical Analysis}

The results were analyzed statistically by using the SPSS BASE 18.0 for windows (SPSS Inc., Chicago, IL) packages. Data were tested by ANOVA and means were analyzed at $P \leqslant 0.05$ and $P \leqslant 0.01$ levels of significant, to determine the significant differences between the two locations and the control, in plants and soils.

\section{Results and Discussion}

\section{Heavy Elements Constituents of $C$. procera at Different Sites}

\begin{abstract}
Aluminum
Accumulation of aluminum elements in leaves of $C$. procera grown at different locations was represented in Fig. (1). During summer season aluminum was highly accumulated in leaves of plants grown at location $2(86.20 \quad \mathrm{mg} / \mathrm{kg} / \mathrm{dry}$ weights $)$ followed by plants at location 1 (46.20 $\mathrm{mg} / \mathrm{kg} / \mathrm{dry}$ weights), while the control plants accumulated a low amount of aluminum (4.20 mg/kg/dry weights). High significant difference was calculated among different locations at $P \leq 0.01$.

During winter season, control plants and plants at location 1 accumulated more aluminum than during summer seasons $(65.80 \mathrm{mg} / \mathrm{kg} /$ dry weights and 72.0 $\mathrm{mg} / \mathrm{kg} /$ dry weights), respectively. However, plants at location 2 showed a slight decrease in the amount of aluminum during this season $(84.0 \mathrm{mg} / \mathrm{kg} /$ dry weights $)$, compared to the amount of aluminum during summer. Nonetheless, plants at location 2 still recorded the highest value, compared to control.
\end{abstract}




\section{Chromium}

Chromium was accumulated in a small amount in all plants during summer season $(\leq 0.001 \mathrm{ppm})$ as was presented in Fig. (2). During winter however, plants at location 1 accumulated an amount of $0.60 \mathrm{mg} / \mathrm{kg} / \mathrm{dry}$ weight, and the control plants recorded 0.06 $\mathrm{mg} / \mathrm{kg} /$ dry weight, but plants at location 2 still have the lowest chromium values $(\leq 0.001 \mathrm{ppm})$.

\section{Boron}

Fig. (3) presents the amount of boron element accumulated in $C$. procera leaves grown at different site in Jeddah city during summer and winter seasons. During summer season, control plants recorded high amount of Boron $(170 \mathrm{mg} / \mathrm{kg} / \mathrm{DW})$, while plants at location 1 recorded $78.0 \mathrm{mg} / \mathrm{kg} / \mathrm{dry}$ weight, compared to plants at location 2, which recorded $(64.0 \mathrm{mg} / \mathrm{kg} / \mathrm{dry}$ weight). During winter however, plants at location 2 recorded the highest value of boron (90.0 $\mathrm{mg} / \mathrm{kg} / \mathrm{dry}$ weight), while plants at location 1 had the lowest values of boron, but still at high level (68.0 mg/kg/dry weight).

\section{Barium}

Barium element accumulation in $C$. procera leaves is presented in Fig. (4). Plants at location 1 accumulated the highest amount of barium compared to control plants (sig. at $P \leq 0.01$ ) and to plants at location 2 (sig. at $P \leq 0.05)$. On the other hand, plants at location 2 accumulated almost double the amount of barium compared to control (8.00 $\mathrm{mg} / \mathrm{kg} /$ dry weights compared to 4.86 $\mathrm{mg} / \mathrm{kg} / \mathrm{dry}$ weight), respectively. During winter season, barium amounts decreased in all plants, but still plants at location one recorded the highest amount of barium, while control plants recorded the least amount $(8.00 \mathrm{mg} / \mathrm{kg} /$ dry weights compared to $3.20 \mathrm{mg} / \mathrm{kg} /$ dry weights), respectively.

\section{Copper}

Copper results were presented in Fig. (5). During summer season plants at location 2 recorded the highest amount of copper (1.60 $\mathrm{mg} / \mathrm{kg} /$ dry weight), while plants at location 1 accumulated low amount of copper $(0.20$ $\mathrm{mg} / \mathrm{kg} / \mathrm{dry}$ weight) and a very small amount of copper was detected in controlled plants $(\leq 0.001 \mathrm{ppm})$. During winter, plants at location 1 accumulated double the amount that was accumulated during winter $(0.40$ $\mathrm{mg} / \mathrm{kg} / \mathrm{dry}$ weight). Copper accumulation in plants at location 2 showed a decrease (from 1.60 to $0.84 \mathrm{mg} / \mathrm{kg} /$ dry weight) between summer and winter, however, plants at location 2 still recorded the highest value of copper at this season.

\section{Manganese}

Results of manganese were presented in Fig. (6). During summer season, plants at location 1 and 2 accumulated almost similar amount of manganese $(54.0 \mathrm{mg} / \mathrm{kg} / \mathrm{dry}$ weight and $52.0 \mathrm{mg} / \mathrm{kg} / \mathrm{dry}$ weight), respectively, which is statistically significantly lower than the control (106.0 $\mathrm{mg} / \mathrm{kg} /$ dry weight at $P \leq 0.01$ ). During winter, control plants still recorded the highest values of manganese $(64.0 \mathrm{mg} / \mathrm{kg} / \mathrm{dry}$ weight), while the plants of the two locations recorded no big difference from summer.

\section{Iron}

Fig. (7) clarified the results of iron accumulated in $C$. procera leaves grown at different sites during summer and winter seasons. During summer season, plants at location 1 accumulated the highest amount of iron, which is significantly higher from the control and from plants at location 2 (at $P \leq 0.01)$. On the other hand, control plants accumulated the lowest amount of iron 
during summer season compared to other locations (10.0 mg/kg/dry weight). During winter however, the rhythm of iron accumulation was highly different than during summer season. Control plants accumulated high amount of iron (86.0 $\mathrm{mg} / \mathrm{kg} / \mathrm{dry}$ weight), while plants at location 1 and 2 recorded almost similar results which were higher than during summer (110.0 $\mathrm{mg} / \mathrm{kg} /$ dry weight and 112.0 $\mathrm{mg} / \mathrm{kg} /$ dry weight), respectively.

\section{Lead}

Fig. (8) indicated the values of lead accumulated in $C$. procera leaves. During summer, plants at location 2 recorded the highest value of lead $(4.68 \mathrm{mg} / \mathrm{kg} / \mathrm{dry}$ weight), which is significantly higher than the control at $P \leq 0.01$. During winter, plants at location 1 recorded the highest values among other locations $(0.60 \mathrm{mg} / \mathrm{kg} / \mathrm{dry}$ weight). Nonetheless, there is no statistical difference was found during winter season.

\section{Zinc}

Zinc values were presented in Fig. (9). During summer, control plants accumulated high amount of zinc (14.91 $\mathrm{mg} / \mathrm{kg} / \mathrm{dry}$ weight), while plants at location 1 and 2 accumulated almost near amounts (5.42 $\mathrm{mg} / \mathrm{kg} /$ dry weight and $6.00 \mathrm{mg} / \mathrm{kg} / \mathrm{dry}$ weight). During winter, however, plants at location 2 recorded the highest value (12.00 $\mathrm{mg} / \mathrm{kg} / \mathrm{dry}$ weight), while plants at location 1 recorded $5.55 \mathrm{mg} / \mathrm{kg} / \mathrm{dry}$ weight, which is significantly lower than the control plants and plants at location 2 (sig. at $P \leq 0.05$ ).

\section{Heavy Elements Constituents of Soil at Different Sites}

\section{Aluminium}

Aluminum as one of the heavy elements accumulated in the soil at different locations during summer and winter as was shown in Fig. (10). Control soils accumulated 116.0 $\mathrm{mg} / \mathrm{kg} / \mathrm{DW}$ during summer, while soil at location 2 accumulated the lowest amount of aluminum (20.39 mg/kg/dry weight), and plants at location 1 accumulated 95.0 ( $\mathrm{mg} / \mathrm{kg} /$ dry weight). This was not the case during winter, control soil recorded the least amount of aluminum during winter (62.0 $\mathrm{mg} / \mathrm{kg} / \mathrm{dry}$ weight), soils at location 1 recorded the highest amount (103.0 $\mathrm{mg} / \mathrm{kg} /$ dry weight), while soil at location 2 recorded a moderate amount of aluminum (80.92 mg/kg/dry weight).

\section{Chromium}

Fig. (11) clarified the results of chromium in different soils during summer and winter. Soils at location 1 accumulated the least amount of chromium $(0.34 \mathrm{mg} / \mathrm{kg} / \mathrm{dry}$ weight), which is significantly less than the control at $P \leq 0.01$. During winter season, however, soil at location 1 accumulated the highest amount of chromium (0.64 $\mathrm{mg} / \mathrm{kg} / \mathrm{dry}$ weight) which is significantly higher than the control at $P \leq 0.01$.

\section{Boron}

Boron amounts accumulated in different soils of the three locations during summer and winter seasons were presented in Fig. (12). During summer, soils at location 1 and 2 recorded similar results $(1.80 \mathrm{mg} / \mathrm{kg} / \mathrm{dry}$ weight), which is slightly lower than the control (2.00 mg/kg/dry weight). During winter, all soils accumulated less amount of boron and soils of location 1 and 2 recorded slightly higher amounts than the control. During this season, soil at location 1 accumulated the higher amount of boron (1.60 mg/kg/dry weight).

\section{Barium}

Fig. (13) represents the amount of barium. 
Barium amount accumulated at different soils during summer and winter, showed no variations between different locations. Generally speaking, Barium was accumulated in a very low quantity either near the factory or far away from it.

\section{Copper}

Copper amount of different soils during summer and winter seasons showed no big variations among the different locations as were presented in Fig. (14). During summer season, soils at location 1 recorded same amount of copper as the control (1.00 $\mathrm{mg} / \mathrm{kg} / \mathrm{dry}$ weight), while soil at location 2 showed a slight increase $(1.40 \mathrm{mg} / \mathrm{kg} / \mathrm{dry}$ weight). During winter season a slight increase in amount of copper was observed in control and soil at location 1 . Nevertheless, soil at location 2 showed a slight decrease in the amount of copper from summer.

\section{Manganese}

Manganese results were presented in Fig. (15). Soils at location 1 recorded the highest value of manganese $(10.0 \mathrm{mg} / \mathrm{kg} / \mathrm{dry}$ weight), while location 2 recorded the least values of manganese $(4.40 \mathrm{mg} / \mathrm{kg} / \mathrm{dry}$ weight). During winter season, soils at location 1 recorded the same value as during summer, while soil at location 2 recorded almost double the amount of manganese during winter season.

\section{Iron}

Fig. (16) represents the amount of iron accumulated in different soils during summer and winter. Iron constituents during summer showed the accumulation of iron elements in location 1 with the same amount as in the control soil $(56.0 \mathrm{mg} / \mathrm{kg} / \mathrm{dry}$ weight), while soil of location 2 showed the least amount of iron $(30.0 \mathrm{mg} / \mathrm{kg} / \mathrm{dry}$ weight). During winter season, however, all soils accumulated less amount of iron than during summer except in case of soil at location 2. Soils at location 1 recorded the highest amount of iron during this season (44.0 $\mathrm{mg} / \mathrm{kg} / \mathrm{dry}$ weight), while there was a pronounced decrease by $67.9 \%$ from summer value.

\section{Lead}

Lead amount for location $1 \& 2$ was less than $0.001 \mathrm{ppm}$, so no representation was made.

Figure.1 The Amount of Aluminum (Mg/Kg/Dry Weight) in Calotropis Procera Leaves Grown at Different Sites During Summer and Winter Seasons

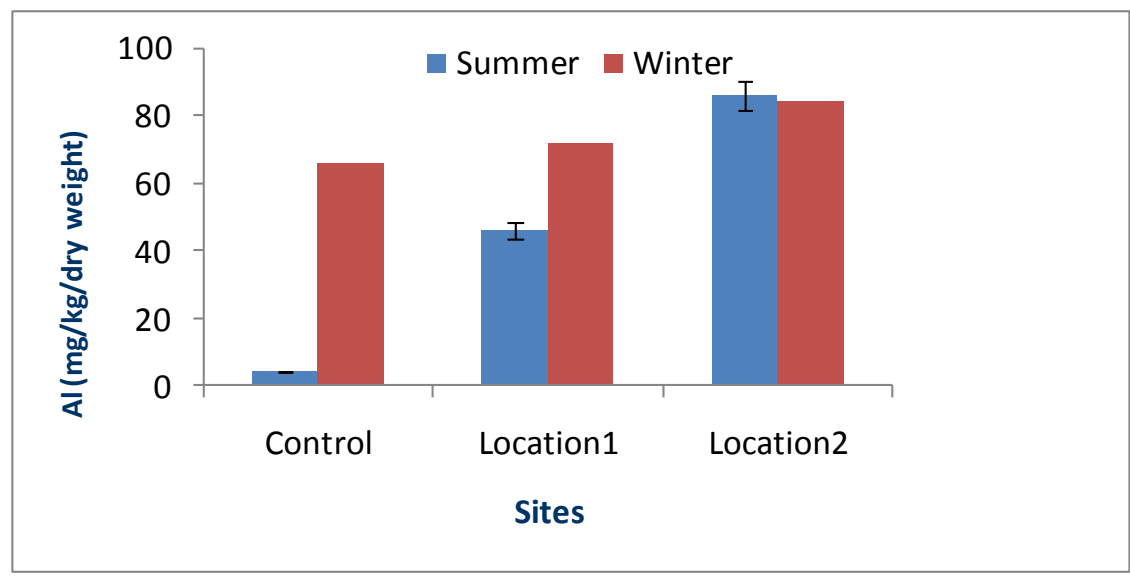


Figure.2 The Amount of Chromium ( $\mathrm{Mg} / \mathrm{Kg} / \mathrm{Dry}$ Weight) in Calotropis procera Leaves at Grown Different Sites During Summer and Winter Seasons

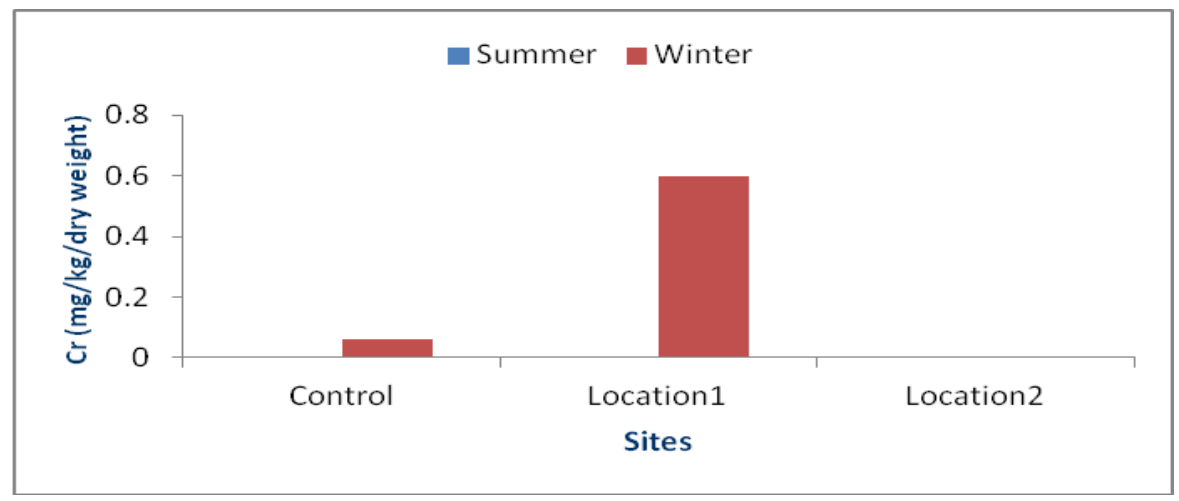

Figure.3 The Amount of Boron (Mg/Kg/Dry Weight) in Calotropis procera Leaves Grown at Different Sites During Summer and Winter Seasons

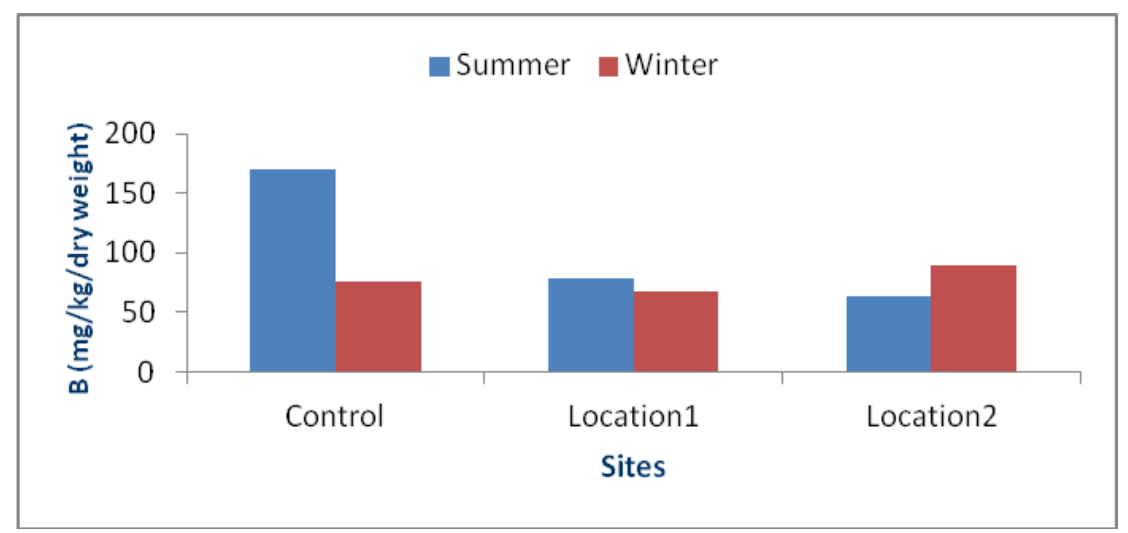

Figure.4 The Amount of Barium (Mg/Kg/Dry Weight) in Calotropis procera Leaves Grown at Different Sites During Summer and Winter Seasons

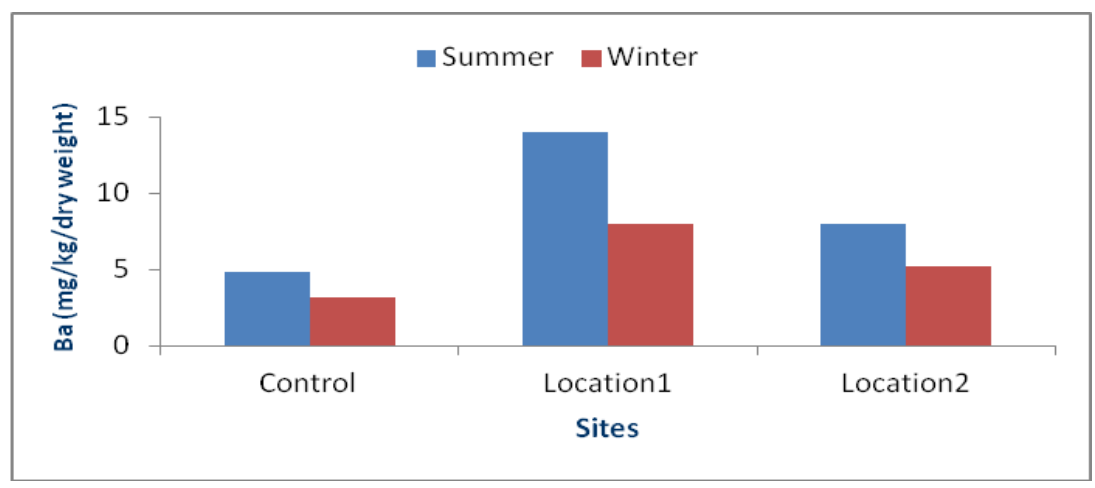


Figure.5 The Amount of Copper ( $\mathrm{Mg} / \mathrm{Kg} / \mathrm{Dry}$ Weight) in Calotropis procera Leaves Grown at Different Sites During Summer and Winter Seasons

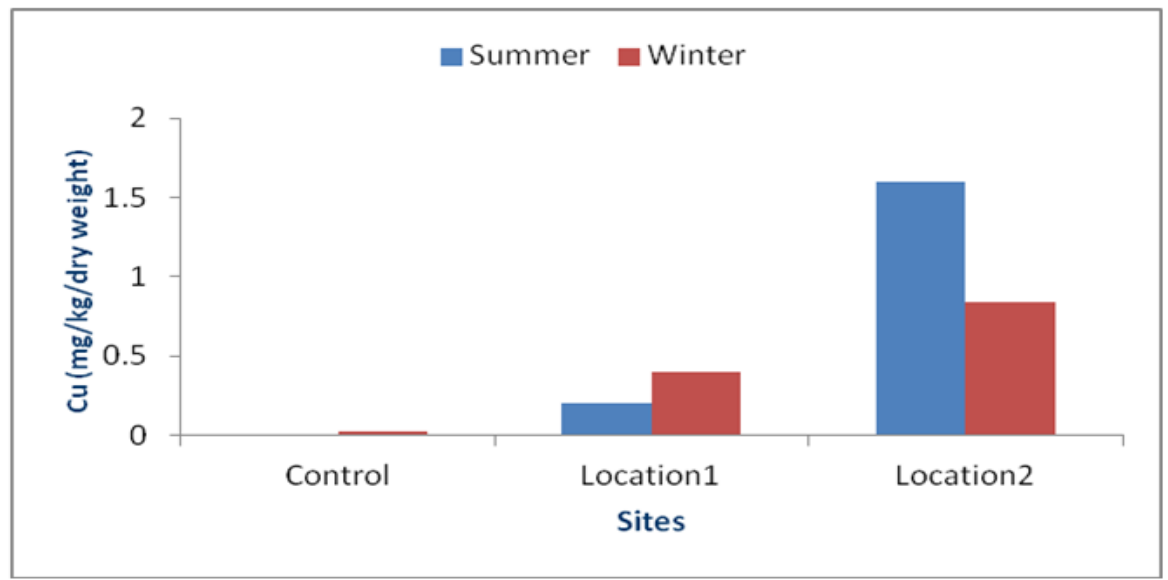

Figure.6 The Amount of Manganese (Mg/Kg/Dry Weight) in Calotropis procera Leaves Grown at Different Sites in Jeddah During Summer and Winter Seasons

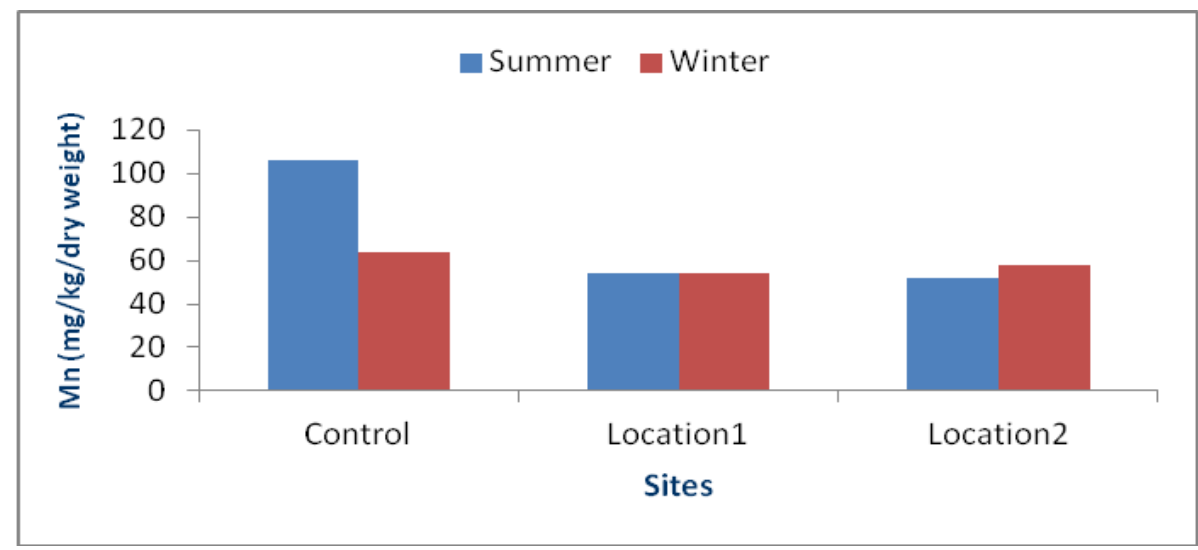

Figure.7 The Amount of Iron (Mg/Kg/Dry Weight) in Calotropis procera Leaves Grown at Different Sites During Summer and Winter Seasons

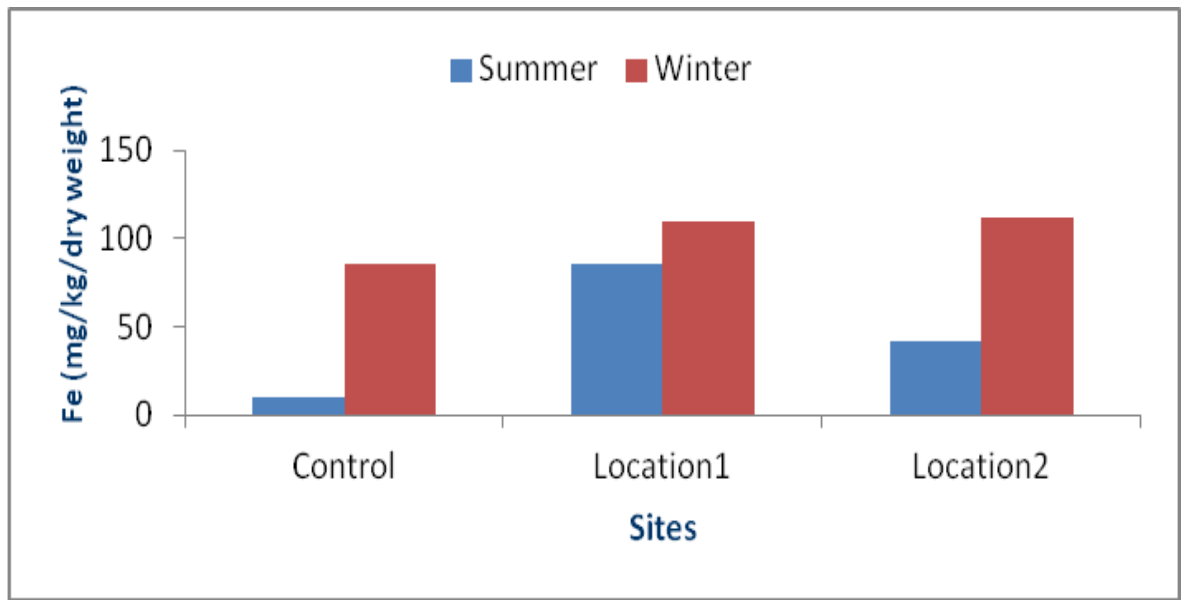


Figure.8 The Amount of Lead (Mg/Kg/Dry Weight) in Calotropis procera Leaves Grown at Different Sites During Summer and Winter Seasons

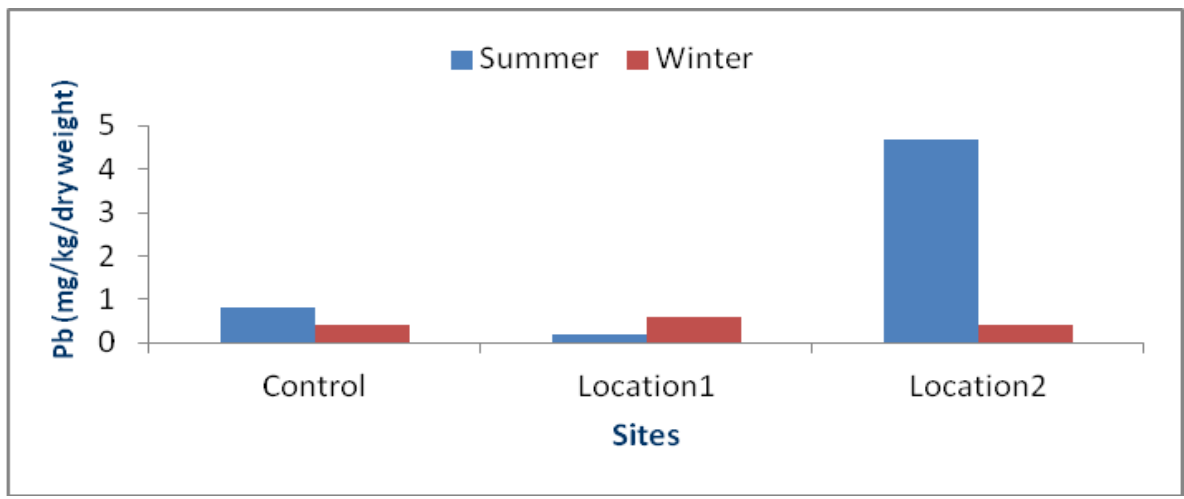

Figure.9 The Amount of Zinc ( $\mathrm{Mg} / \mathrm{Kg} / \mathrm{Dry}$ Weight) in Calotropis procera Leaves Grown at Different Sites During Summer and Winter Seasons

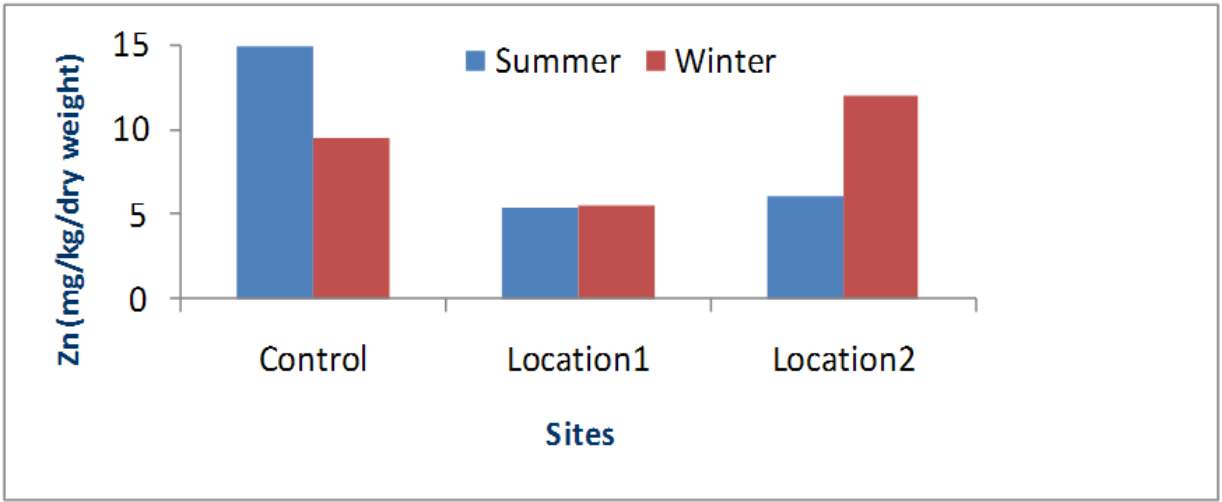

Figure.10 The Amount of Aluminum ( $\mathrm{Mg} / \mathrm{Kg} /$ Dry Weight) in Soil at Different Sites in Jeddah During Summer and Winter Seasons

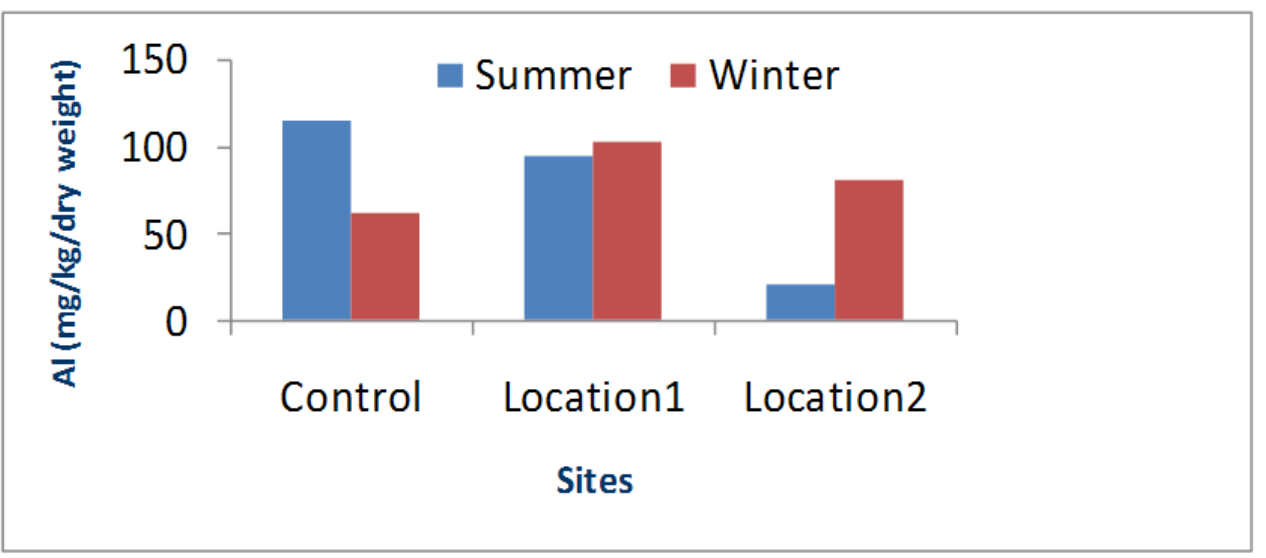


Figure.11 The Amount of Chromium (Mg/Kg/Dry Weight) in Soil at Different Sites in Jeddah During Summer and Winter Seasons

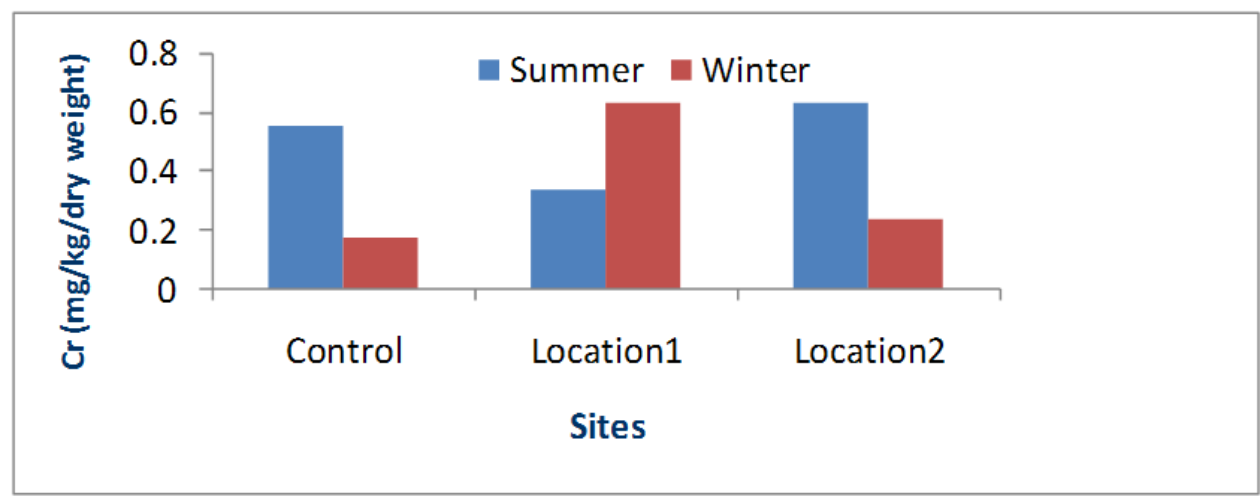

Figure.12 The Amount of Boron (Mg/Kg/Dry Weight) In Soil at Different Sites in Jeddah During Summer and Winter Seasons

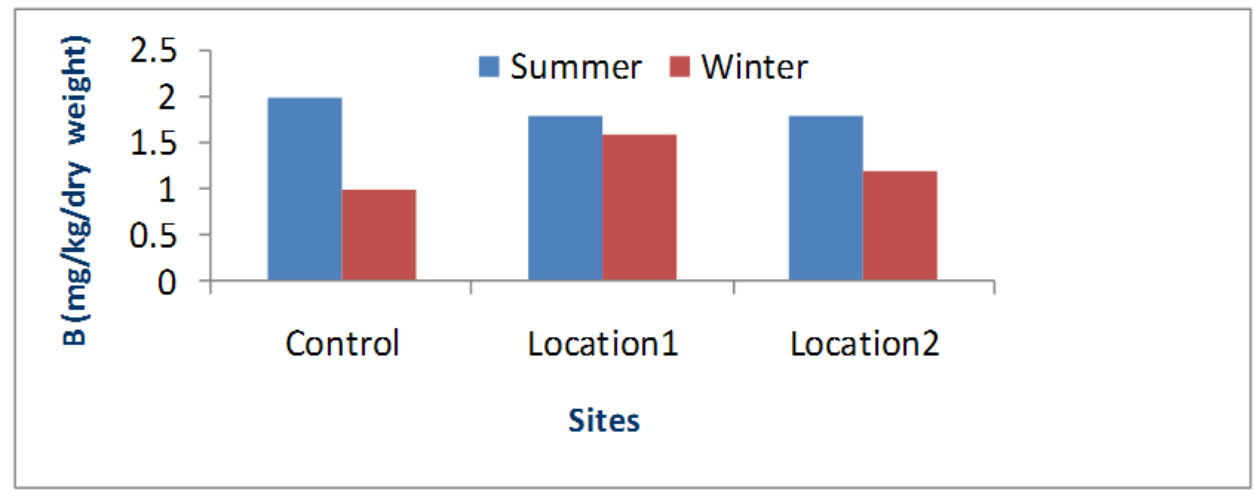

Figure.13 The Amount of Barium (Mg/Kg/Dry Weight) in Soil at Different Sites in Jeddah During Summer and Winter Seasons

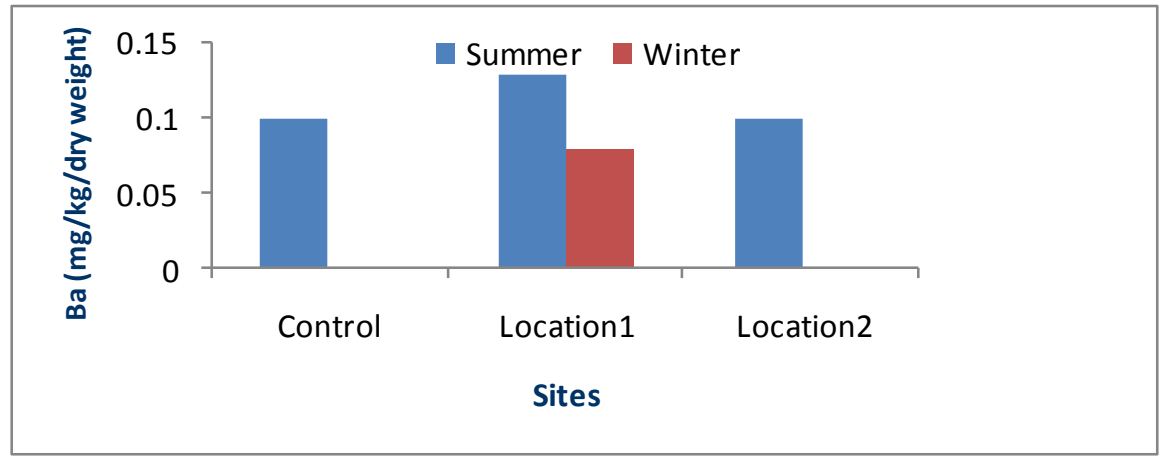


Figure.14 The Amount of Copper (Mg/Kg/Dry Weight) in Soil at Different Sites in Jeddah During Summer and Winter Seasons

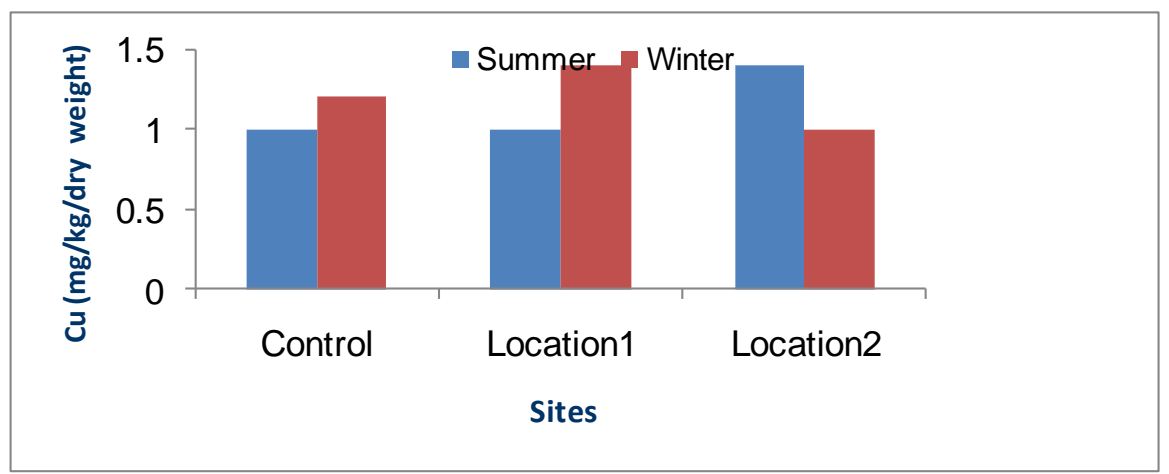

Figure.15 The Amount of Manganese (Mg/Kg/Dry Weight) in Soil at Different Sites in Jeddah During Summer and Winter Seasons

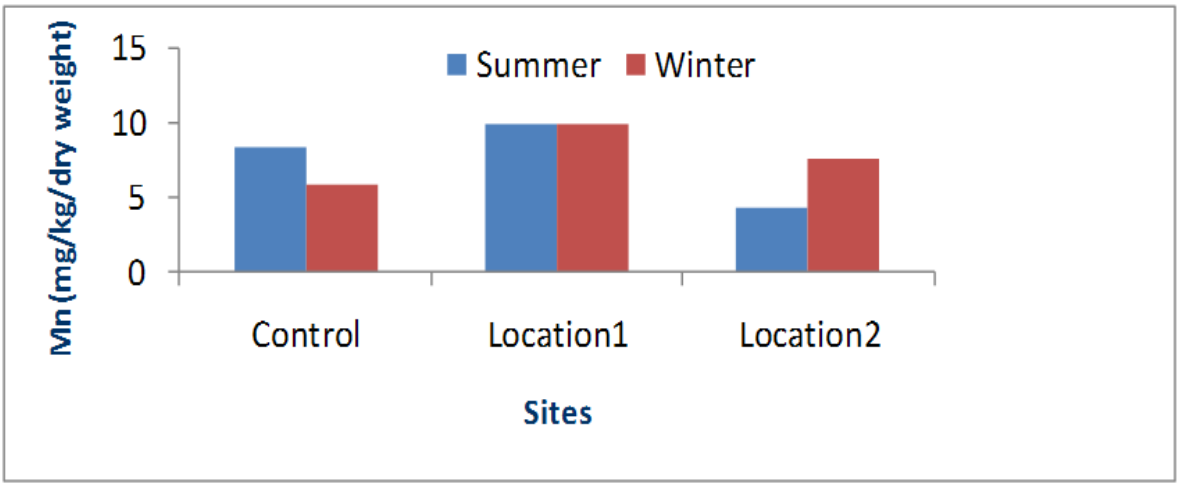

Figure.16 The Amount of Iron ( $\mathrm{Mg} / \mathrm{Kg} /$ Dry Weight) in Soil at Different Sites in Jeddah During Summer and Winter Seasons

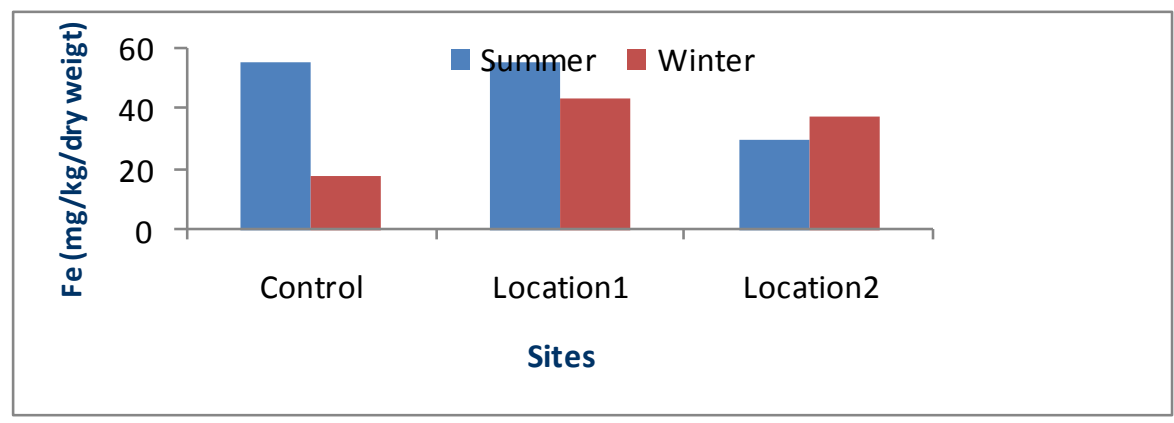


Figure.17 The Amount of Zinc ( $\mathrm{Mg} / \mathrm{Kg} /$ Dry Weight) in Soil at Different Sites in Jeddah During Summer and Winter Seasons

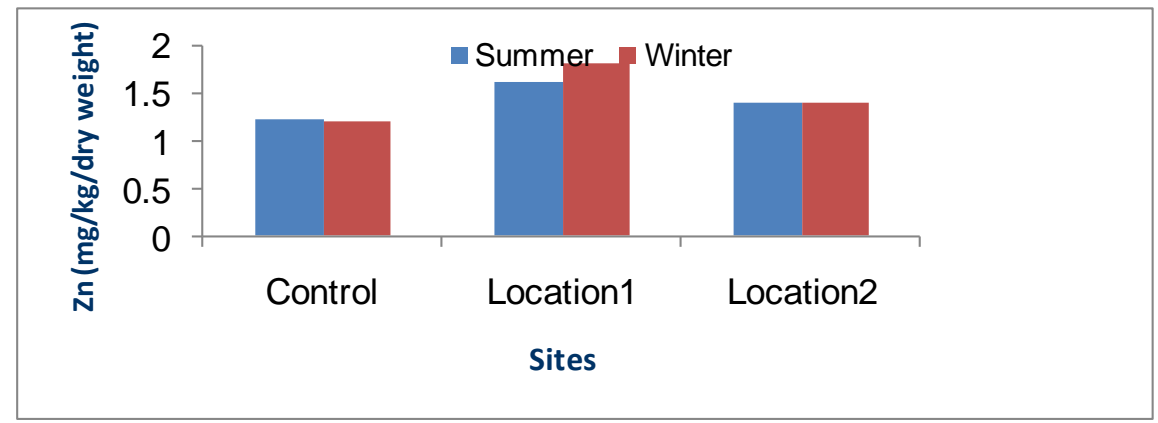

Picture.1 C. procera at Flowering and Fruiting Stages
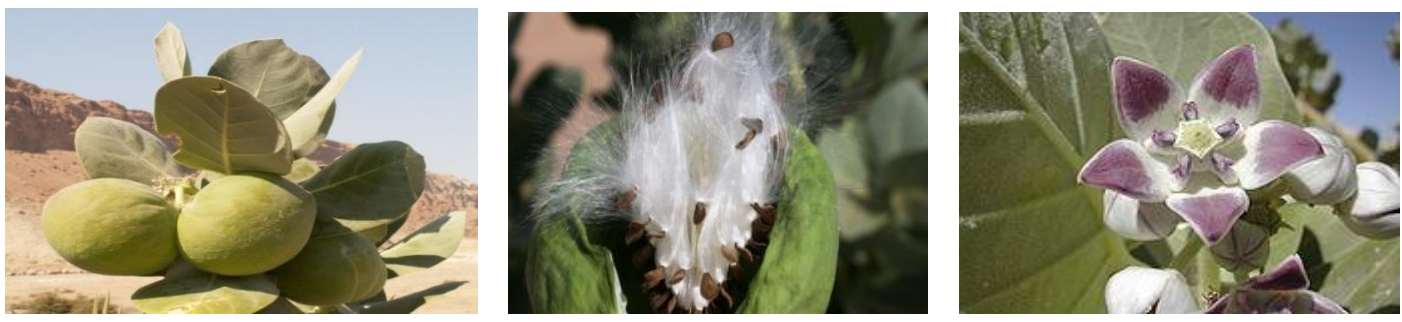

Picture.2 A Photograph of the Factory with Some Plants of Location
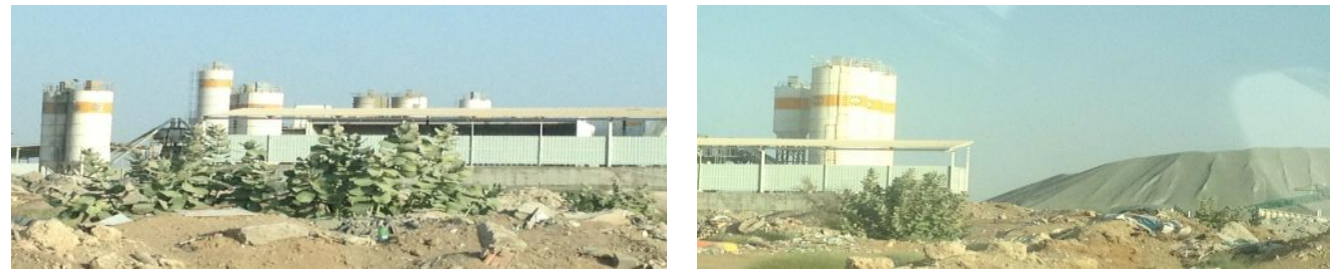

\section{Zinc}

Fig. (17) presents the values of zinc in different soils during summer and winter. There were no statistical differences between the soils of two locations and the control either during summer or winter seasons. Nonetheless, soils at location 1 reported the higher values of zinc, while control soils have the lowest values during the two seasons.

The toxic elements found in the cement dust

are drastic in spreading pollution. Cement dust affects the presence of some plant species more than one grown far away. Heavy metals like, zinc, copper, beryllium, sulphuric acid, hydrochloric acid manganese, iron and lead were associated with cement factories (Chaurasia et al., 2013).

It was noticeable that leaves of the $C$. procera at location 2 (the factory site) contain more amount of elements like ferrous, manganese and lead during summer 
which ensure that the area is exposed to air pollution from the cement factory. The plants looks like have no tools in the upper part, and so heavy metals were absorbed directly from air. These results are similar to those of Tulyan and Farraj, (2002). Moreover, $\mathrm{Cr}$ and $\mathrm{Cu}$ had the lowest level of accumulation in plants than other elements at all locations. These results were in consistence with those of Tulyan and AlFarraj, (2002) and Ramamurthy and Kannan, (2009). This means that, C. procera could be used as an indicator of many heavy elements pollutants in plants and soils. Copper is essential for nutrition of plants in addition to so many enzymes activities such as oxidation-reduction. $\mathrm{Cu}$ tends to accumulate in roots and is scarcely translocated into aboveground organs (Domez and Aksu, 2001; Tulyan and AlFarraj, 2002; and Oyedepo, 2011). In the present study, $\mathrm{Cu}$ concentrations on roots were not taken. Chromium on the other hand, was found by Zou et al., (2006) and Chidambaram et al., (2009) to be accumulated more in the roots. Chromium is a well known toxic element.

Regarding the seasonal variations in elements accumulation during summer and winter, it was noticeable that, in most cases the values of heavy elements $(\mathrm{Al}, \mathrm{B}, \mathrm{Cr}, \mathrm{Cu}$, $\mathrm{Fe}, \mathrm{Mn}$ and $\mathrm{Zn}$ ), in plants at location 1 and 2 were high during winter season. These results are in agreements with those of Birnin et al., (2011), who concluded that accumulated during the rainy season. In Jeddah province winter is the rainy season. Soil is an important part of the globe since it is not only the store for pollutants, but also the natural place for transferring elemnts to the ecosystem. Different kinds of heavy elements which originated from various sources may finally reach the surface soil, and their further fate depends on soil chemical and physical properties (Flathman and Lanza, 1998). All toxic metals when they are concentrated in a place, have poisonous effects and are considered as hazardous pollutants. In the present study, the concentrations of the investigated heavy metals in soil possess the sequence of $(\mathrm{Al}>$ $\mathrm{Fe}>\mathrm{Mn}>\mathrm{Zn}>\mathrm{Cu}>\mathrm{B}>\mathrm{Cr}>\mathrm{Ba}>\mathrm{Pb}$ ). Worth mentioning is that, lead $(\mathrm{Pb})$, was detected in a very low concentration in soils of location 1 and $2(\leq 0.001 \mathrm{ppm})$. Seasonal variation in elements accumulation in soil during summer and winter, clarified that, heavy elements in soil, Al, Ba, B, Cr (except for location 1), Fe, Mn (except for location 2 ), were high in summer more than during winter. On the other hand, Zinc accumulation in soil followed the same pattern during summer and winter season. Accumulation of heavy elements during summer in soils, was also reported by Tulyan and Al-Farraj, (2002) and Mohammed and Ibrahem, (2014).

In conclusion, almost all heavy elements are less in soil than in plants at locations 1 \& 2, compared to control, indicating that air pollution significantly increased the heavy elements concentration in leaves. This indicates the ability of $C$. procera to absorb and clean heavy elements from the soil. Indicating the phytoremediation ability of this plant in cleaning the soil, meaning that, this plant absorbs the pollutants from the atmosphere and can be used as protective belt near factories.

\section{References}

Al-Yemni, M., Sher, H., El-Sheikh, M., Eid, E. 2011. Bioaccumulation of nutrient and heavy metals by Calotropis procera and Citrullus colocynthis and their potential use as contamination indicators. Sci. Res. Essays, Vol. 6(4), pp. 966-976. ISSN 1992-2248.

Birnin-Yauri, I., Yahaya, Y., Bagudo, Noma, S.S. 2011. Seasonal variation in nutrient 
content of some selected vegetables from Wamakko, Sokoto State, Nigeria. J. Soil Sci. Environ. Management, Vol. 2(4): 117-125.

Chaurasia, S., Karwaria, A., Gupta, A.D. 2013. Cement dust pollution and morphological attributes of groundnut (Arachis hypogaea ), Kodinar, Gujrat, India. IOSR J. Environ. Sci. Toxicol. Food Technol., Volume 4, Issue 1, pp 20-25. e-ISSN 2319-2402, p- ISSN 2319-2399.

Chidambaram, A., Sundaramoorthy, P., Murugan, A., Sankar, K., Ganesh, B.L. 2009. Chromium induced cytotoxicity in blackgram (Vigna mungo L.) Iran. J. Environ. Health Sci. Eng., 6(1): 17-22.

Dömez, G., Aksu, Z. 2001. Bioaccumulation of copper (II) and nickel (II) by the no adapted and adapted growing Candida sp. Water Res., (35): 1425-1434.

Flathman, P.E., Lanza, G.R. 1998. Phytoremediation: current views on an emerging green technology. J. Soil Contamination., 7: 415-432.

Heng, L., Jingyu, R., Wen, Y., Xiaohai, L., Jiaqiang, W., Wudi, Z. 2009. Removal of phosphate from polluted water by lanthanum doped vesuvianite. J. Hazard. Mater., 168(1): 326-330.

Hifsa, M., Ismat, N., Abida, T. 2010. Phytoremediation of $\mathrm{Cu}(\mathrm{II})$ by Calotropis procera roots. New York Sci. J., 3(3): 1-5. ISSN 1554-0200.

Hifsa, M., Ismat, N., Abida, T. 2010. Removal of $\mathrm{Pb}$ (II) from aqueous solutions using Calotropis procera roots in a Fixed-Bed Column. Report and Opinion, 2(11): 22 26. ISSN 1553-9873.
Mohammed, N.A., Ibrahem A.A. 2014. Traffic and industrial activities around Riyadh cause the accumulation of heavy metals in legumes: A case study. Saudi J. Biol. Sci., 21(2): 167-172.

Oyedepo, T.A. 2011. Biosorption of lead (II) and copper (II) metal ions on Calotropis procera (Ait.). Sci. J. Pure \& Appl. Chem., Vol. 2(3): 12-24.

Ramamurthy, N., Kannan, S. 2009. Analysis of soil and plant (Calotropis gigantea Linn) collected from an industrial village, Cuddalore DT, Tamil Nadu, India. Romanian J. Biophys., Vol. 19, No. 3, pp. 219-226.

Stewart, E.A. 1983. Chemical Analysis of Ecological Materials. Black Well Scientific London.

Tulyan, H.N., Al-Farraj, M.M. 2002. Pollution measurement by some heavy metals in Riyadh, Saudi Arabia using Calotropis procera as bioindicator Copper. Saudi J. Biol. Sci., 9(2): 32- 39.

Vaishnav, V., Daga, K., Chandra, S., Lal, M. 2012. Adsorption studies of $\mathrm{Zn}$ (II) ions from wastewater using Calotropis procera as an Adsorbent. Res. J. Recent. Sci., 160-165. ISSN 2277 - 2502.

Volesky, B. 1994. Advances in biosorption of metals: selection of biomass types. FEMS Microbiol. Rev., (14): 291-302.

Volesky, B., Holan, Z.R. 1995. Biosorption of Heavy Metals. Biotechnol. Progress, 11(3): 235-250.

Zou, J.H., Wang, M., Jiang, W.S., Liu, D.H. 2006. Effects of hexavalent chromium (VI) on root growth and cell division in root tip cells of Amaranthus viridis, L. Pak. J. Bot., 38(3): 673- 681.

\section{How to cite this article:}

Batoul Mohamed Abdullatif, Molouk Mohamed El-Kazan and Maram Ali Al-Zahrani. 2016. Phytoremediation Ability of Calotropis procera in Reducing Air Pollution in Jeddah CityKingdom of Saudi Arabia. Int.J.Curr.Microbiol.App.Sci. 5(3): 212-225. doi: http://dx.doi.org/10.20546/ijcmas.2016.503.026 